\title{
Research on Saving and Intensive Evaluation Indicator System of Rural Infrastructure Construction
}

\author{
Xinwei $\mathrm{Li}^{1, \mathrm{a}}$, Ying Cao ${ }^{2, \mathrm{~b}}$, Lili Zhang ${ }^{3, \mathrm{c}}$ and Pengfei Qiü,d \\ ${ }^{1}$ Urban and Rural Development College, Sichuan Agricultural University, 288\# Jianshe Road, Du \\ Jiangyan, Sichuan Province, China \\ ${ }^{2}$ Urban and Rural Development College, Sichuan Agricultural University, 288\# Jianshe Road, Du \\ Jiangyan, Sichuan Province, China \\ ${ }^{3}$ Urban and Rural Development College, Sichuan Agricultural University, 288\# Jianshe Road, Du \\ Jiangyan, Sichuan Province, China \\ ${ }^{4}$ Bazhong Urban Planning Bureau, 160\# Jiangbei Avenue, Bazhong, Sichuan Province, China

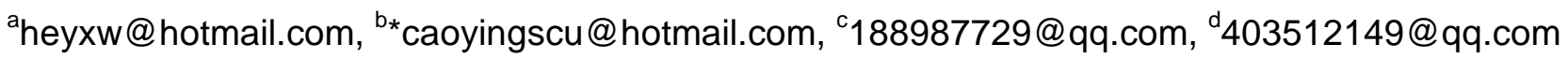

Keywords: Country, Infrastructure, Saving and Intensive, Evaluation Indicator System

Abstract. This paper proposed an indicator system to the saving and intensive of infrastructure. The evaluation indicator system was built from three dimensions - transportation facilities evaluation indicator, water supply and drainage facilities evaluation indicator, safety and disaster prevention facilities evaluation Indicator. The saving and intensive extent of rural infrastructure would be quantitatively evaluated by this indicator system to build livable living environment.

\section{Introduction}

Existing research of saving and intensive evaluation indicator basically focus on in urban areas with high concentration of resources. Most of them take land use as research objects, which lead to omit the research on villages. Disorderly and lowly intensive construction of rural generally caused two extreme results - infrastructure allocation is low/zero or overdone, humane living environment is not humanized and resources are wasted ${ }^{[1]}$. From this perspective, research to intensive on village level has importantly practical significance. This paper committed to establish infrastructure evaluation indicator system.

\section{Saving and intensive evaluation indicator system of rural infrastructure}

Infrastructure is mostly permanent construction which is long duration, large investment and high risk $^{[2]}$.The World Bank pointed out that in order to respond to some social issues such as social stability, rapid urbanization, climate change and natural disasters, food and energy security, departments need to be linked through infrastructure's complexity and connectivity ${ }^{[3]}$.

Conformed to the high demand by new urbanization for the intensive use of resources, it is necessary and urgent to build the index system for saving and intensive of infrastructure ${ }^{[4]}$. For its unique nature and urban evaluation system to distinguish, research on village differs from that in urban. This paper attempts to establish an indicator system of rural infrastructure construction to provide a quantitative evaluation method to evaluate the intensive degree of rural infrastructure.

In this paper, infrastructure sharing rate evaluation system were proposed with three aspects transportation facilities evaluation indicator, water supply and drainage facilities indicator, safety and disaster prevention facilities evaluation indicator. The infrastructure sharing rate evaluation system could be set in accordance with Table 1 . 
Table 1 Infrastructure sharing rate evaluation system

Target Layer

Criterion Layer

Evaluation Layer

Transportation

Road quality indicators

facilities

evaluation

indicator

Traffic indicators

Saving and Intensive Evaluation Indicator System of Rural Infrastructure Construction

\begin{tabular}{cc}
\hline & Resource utilization \\
\cline { 2 - 2 } $\begin{array}{c}\text { Water supply } \\
\text { and drainage } \\
\text { facilities indicator }\end{array}$ & Structures sharing rate \\
\cline { 2 - 2 } & Facilities coverage \\
\hline $\begin{array}{c}\text { safety and disaster } \\
\text { prevention } \\
\text { facilities } \\
\text { evaluation } \\
\text { indicator }\end{array}$ & Flood control \\
\cline { 2 - 2 } & Felief lifeline engineering \\
\hline
\end{tabular}

\section{Complexity and connectivity evaluation indicator system on rural infrastructure}

Transportation facilities evaluation indicator. As one of the most important construction projects, transportation facilities are prerequisites for regional development. Furthermore, rural road infrastructure is an important indicator to evaluate the development of socio-economic. Existing road infrastructure in rural areas is insufficient and fragmented which leads to disconnection between village and village, villages and regional center. As a result, the development of the region is hesitated. Considered to build road quality indicators with area density of road network, road paved rate and road greening rate. In the same way, build traffic indicators with road network load degree, connectivity rate and mastery rate. Transportation facilities evaluation could be set in accordance with Table 2 .

Table 2 Share-ratio-based indicator system for the assessment of road transport infrastructure

\begin{tabular}{|c|c|c|c|}
\hline Target Layer & Criterion Layer & Evaluation Layer & Index Description \\
\hline \multirow{6}{*}{$\begin{array}{l}\text { Road transport } \\
\text { infrastructure } \\
\text { sharing rate } \\
\text { index }\end{array}$} & \multirow{3}{*}{$\begin{array}{l}\text { Road quality } \\
\text { indicators }\end{array}$} & Area density of road network & $\begin{array}{l}\text { The total length of roads / The } \\
\text { total land area }\end{array}$ \\
\hline & & Road paved rate & $\begin{array}{l}\text { Road surface has hardened area / } \\
\text { The total area of the road }\end{array}$ \\
\hline & & Road greening rate & $\begin{array}{l}\text { Reach the green standard of the } \\
\text { road edge area / The total area of } \\
\text { the edge of the road }\end{array}$ \\
\hline & \multirow[b]{3}{*}{ Traffic indicators } & Road network load degree & Actual traffic / Capacity \\
\hline & & Road Network Connectivity & $\mathrm{C}=\frac{\sum_{i-1}^{n} m}{\mathrm{~N} m}$ \\
\hline & & Road network accessibility rate & $\begin{array}{l}\text { The sum of the number of } \\
\text { residents in points and patches of } \\
\text { land to meet the transport needs } \\
\text { of the road / Residents sum of } \\
\text { points and number of patches of } \\
\text { land }\end{array}$ \\
\hline
\end{tabular}

The Water supply and drainage facilities evaluation indicator. Water supply and drainage facilities evaluation is evaluated from three levels -resource utilization, structures sharing rate, 
facilities coverage. Taking into account both indicators and access to data, water supply and drainage facilities evaluation could be set in accordance with Table 3 .

Table 3 Share-ratio-based indicator system for the assessment of water supply and drainage facilities infrastructure

\begin{tabular}{|c|c|c|c|}
\hline Target Layer & Criterion Layer & Evaluation Layer & Index Description \\
\hline \multirow{6}{*}{$\begin{array}{l}\text { Water supply } \\
\text { and drainage } \\
\text { facilities } \\
\text { evaluation }\end{array}$} & $\begin{array}{l}\text { Resource } \\
\text { utilization }\end{array}$ & Effective irrigation rate & $\begin{array}{l}\text { Effective irrigation area / Arable } \\
\text { land }\end{array}$ \\
\hline & \multirow{2}{*}{$\begin{array}{l}\text { Structures } \\
\text { sharing rate }\end{array}$} & $\begin{array}{c}\text { Per capita occupancy to water } \\
\text { pipeline }\end{array}$ & $\begin{array}{l}\text { The length of water pipeline / The } \\
\text { number of actual coverage }\end{array}$ \\
\hline & & Per capita occupancy to drains & $\begin{array}{l}\text { The length of drains / The number } \\
\text { of actual coverage }\end{array}$ \\
\hline & \multirow{3}{*}{$\begin{array}{l}\text { Facilities } \\
\text { coverage }\end{array}$} & Water supply network coverage & $\begin{array}{l}\text { The number of people covered by } \\
\text { water supply network / Total } \\
\text { population }\end{array}$ \\
\hline & & Drainage network coverage & $\begin{array}{l}\text { The number of people covered by } \\
\text { water drainage network / Total } \\
\text { population }\end{array}$ \\
\hline & & $\begin{array}{c}\text { Sewage collection and treatment } \\
\text { system coverage }\end{array}$ & $\begin{array}{l}\text { The number of people covered by } \\
\text { sewage collection and treatment } \\
\text { system / Total population }\end{array}$ \\
\hline
\end{tabular}

Safety and disaster prevention facilities evaluation indicator. Build safety and disaster prevention facilities evaluation indicator comprehensively from four indexes - flood control, firefighting, relief lifeline engineering, peace and disaster combined. Considering to the index data access to factors, safety and disaster prevention facilities evaluation could be set in accordance with Table 4.

Table 4 Share-ratio-based indicator system for the assessment of safety and disaster prevention infrastructure

\begin{tabular}{|c|c|c|c|}
\hline Target Layer & Criterion Layer & Evaluation Layer & Index Description \\
\hline \multirow{5}{*}{$\begin{array}{l}\text { Safety and } \\
\text { disaster } \\
\text { prevention } \\
\text { infrastructure } \\
\text { sharing rate } \\
\text { index }\end{array}$} & \multirow{2}{*}{ Flood control } & $\begin{array}{l}\text { Flood control equipment building } \\
\text { rate }\end{array}$ & $\begin{array}{l}\text { Number of build equipments / } \\
\text { Number of equipments have been } \\
\text { built }\end{array}$ \\
\hline & & Drainage facilities building rate & $\begin{array}{l}\text { Area of drainage facilities } \\
\text { covering / Area of administrative } \\
\text { region }\end{array}$ \\
\hline & Firefighting & Fire exits connectivity & $\begin{array}{l}\text { Width of more than four meters } \\
\text { of road length / The total length } \\
\text { of roads }\end{array}$ \\
\hline & $\begin{array}{l}\text { Relief lifeline } \\
\text { engineering }\end{array}$ & Per capita area of relief square & $\begin{array}{l}\text { Area of relief square / Resident } \\
\text { population }\end{array}$ \\
\hline & $\begin{array}{l}\text { Peace and disaster } \\
\text { combined }\end{array}$ & $\begin{array}{l}\text { Usage of disaster prevention } \\
\text { park/square in peace }\end{array}$ & $\begin{array}{l}\text { Time per visitor stay in relief } \\
\text { square for once / Resident } \\
\text { population }\end{array}$ \\
\hline
\end{tabular}

\section{Summary}

The main objective of infrastructure construction in rural area is upgrade of existing facilities. This paper proposed the scheme of the evaluation indicator in three dimensions with six aspects transportation facilities, water supply and drainage facilities, energy and power facilities, post and telecommunications facilities, ecological environment facilities, safety and Disaster prevention facilities. Through establishing a scientific conservation and rural infrastructure construction intensive evaluation 
indicator system, investigate and quantify the way for the construction of country to guide the building of beautiful towns and villages.

\section{Acknowledgements}

This work was financially supported by the Sichuan Center for Rural Development Research Science Foundation (CR1204), the Sichuan Education Department of Sichuan Province Science Foundation (13ZB0277), the Sichuan Agricultural University of Federation of Social Sciences Circle Social Science Foundation (xck201207), the Sichuan Agricultural University of Research Interest Training Program (2014332) and the Sichuan Agricultural University of Students Innovation Experiment Program (201410626090).

\section{References}

[1] Li ZhiJun. Study on Adjustment of China's Rural Infruastructure Configuration [D]. Northeast Normal University doctoral dissertation, 2011.

[2] Sun Jian. Study on the Synthesis Evaluation Indicator System and Application of Infrastructure Projects [D]. Tsinghua University, 2004.

[3] Information on

http://web.worldbank.org/WBSITE/EXTERNAL/TOPICS/EXTINFRA/0,,menuPK:8430735 pageP K:64168427 piPK:64168435 theSitePK:8430730,00.html

[4] The Central Committee of the Communist Party of China, State Council. National New Urbanization Planning (2014-2020) [D]. 